\title{
Whole-grain pan bread with the addition of jabuticaba peel flour
}

\author{
Sumaya Patiara Lima Ferreira ${ }^{1}$ (D) Fernanda Barbosa Borges Jardim $^{2 *}$ (iD \\ Carolina Rodrigues da Fonseca ${ }^{2}$ Luciene Lacerda Costa $^{2}$ (D)
}

${ }^{1}$ Departamento do Curso Técnico em Alimentos, Instituto Federal do Paraná (IFPR), Jacarezinho, PR, Brasil.

${ }^{2}$ Departamento de Pós-graduação em Ciência e Tecnologia de Alimentos, Instituto Federal de Educação, Ciência e Tecnologia do Triângulo Mineiro (IFTM), 38064-790, Uberaba, MG, Brasil. E-mail: fernanda.jardim@iftm.edu.br. "Corresponding author.

ABSTRACT: The objective of this study was to analyze the potential of the jabuticaba peel flour (JPF) as an ingredient in whole-grain bread. Pan bread formulations with different concentrations of jabuticaba peel flour were made: $0 \%$ (T0), 5\% (T1), 10\% (T2), and 15\% (T3). Proximate composition, $\mathrm{pH}$, water activity, color, phenolic compounds and antioxidant activity of bread were determined. The addition of JPF to the bread formulations led to a reduction of carbohydrate levels (51.14 to $\left.46.55 \mathrm{~g} 100 \mathrm{~g}^{-1}\right)$, lipids (4.79 to $\left.3.35 \mathrm{~g} 100 \mathrm{~g}^{-1}\right)$ and an increase in

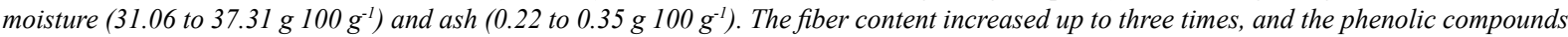
up to seven times, thus increasing the antioxidant activity of the JPF-based bread when compared to the control. Bread made with the addition of JPF presented lower $L^{*}$ values (46.72 to 36.07) and higher $a^{*}$ values (3.10 to 9.07) compared to the control. Therefore, jabuticaba peel flour can be considered a potential ingredient for addition to whole-grain pan bread with desirable nutritional and functional characteristics. Key words: antioxidants, Myrciaria jaboticaba, baking, nutrition.

Pães de forma integrais com adição de farinha de casca de jabuticaba

RESUMO: Este trabalho teve como objetivo analisar o potencial da farinha de casca de jabuticaba (FCJ) como ingrediente em pães de forma integrais. Foram elaboradas formulações de pães com diferentes concentrações de farinha de casca de jabuticaba: $0 \%$ (T0), 5\% (T1), $10 \%$ (T2) e 15\% (T3). Foram realizadas análises de composição centesimal, pH, atividade de água, cor, compostos fenólicos e atividade antioxidante dos pães. A adição de FCJ às formulações de pão levou a uma redução dos níveis de carboidratos (51,14 a $\left.46,55 \mathrm{~g} 100 \mathrm{~g}^{-1}\right)$,

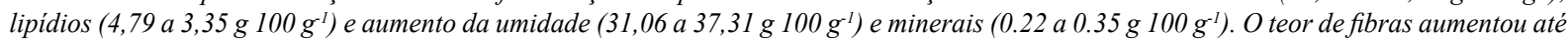
três vezes e os compostos fenólicos até sete vezes, aumentando a atividade antioxidante do pão à base de FCJ quando comparado ao controle. $O$ pão elaborado com a adição de FCJ apresentou menores valores de $L^{*}(46,72$ a 36,07) e maiores valores de a* $(3,10$ a 9,07$)$ em relação ao controle. Portanto, a farinha de casca de jabuticaba pode ser considerada um ingrediente potencial para a adição ao pão de forma integral com características nutricionais e funcionais desejáveis.

Palavras-chave: antioxidante, Myrciaria jaboticaba, pães, nutrição.

\section{INTRODUCTION}

The growing concern about consuming healthy foods has spurred the food industry to look for new sources of ingredients. The full use of food appears as an alternative to diversify the options of raw materials, since husks and seeds are the least consumed parts and are sources of fibers and minerals (STORCK et al., 2013). Jabuticaba is a fruit with great potential to be used in the manufacture of functional foods and has been gaining prominence due to its nutritional and therapeutic benefits that fit it in the list of super fruits (ALEZANDRO et al., 2013; CHANG et al., 2019). Jabuticaba is a Brazilian tropical fruit that has white pulp and dark colored film, and is consumed fresh or processed in juices, jellies, wines and liquors (WU et al., 2012; QUATRIN et al., 2019).

In the production of jabuticaba juice, coproducts represent $60 \%$ of the fruit's weight (GURAK et al., 2014). The peel represents up to $43 \%$ of the fruit and contains high concentrations of polyphenols, anthocyanins, phenolic acids, flavonoids, quercetin, gallic acid and epicatechin, in addition to being a source of fibers and minerals (LEITE-LEGATTI et 
al., 2012; PLAZA et al., 2016; LAMAS et al., 2018; LIMA, et al., 2008).

The increased demand for nutritional diversification makes pan bread an excellent alternative for enrichment. Several studies are being carried out with the aim of improving the nutritional value of foods using jabuticaba peels due to its ability to be used as a natural pigment and vehicle for bioactive compounds in food products (WU et al., 2013; FREITAS-SÁ et al., 2018; OLIVEIRA et al., 2019). Therefore, there is an interest of adding powder of jabuticaba peel to the bread to make it more nutritious. The aim of this study was to produce whole grain bread with the addition of different concentrations of jabuticaba peel flour and to evaluate the product's physical-chemical characteristics.

\section{MATERIALS AND METHODS}

\section{Production of jabuticaba peel flour}

Mature jabuticaba (Myrciaria jaboticaba), variety Sabará, was donated by the community of the city of Jacarezinho-PR, Brazil, in September 2016. Soon after, the raw material was selected and sanitized. Then, the jabuticaba flesh was manually removed, and peels were layered in aluminum baking sheets. The peels were dried in an oven with forced air circulation (Lucadema, 82/480 model, Brazil) at $60{ }^{\circ} \mathrm{C}$ for $12 \mathrm{~h}$ (FERREIRA et al., 2012), and crushed using a domestic blender (Britânia, B1000 model, Brazil) at a maximum speed. The resulting flour was vacuum packed in high-density polyethylene bags (Selovac, DZ300T, Brazil) and stored at $-18{ }^{\circ} \mathrm{C}$ until use.

Production of pan bread with the addition of jabuticaba peel flour

The pan bread was made according to a standard formulation (conventional whole-grain bread), consisting of a control treatment and three treatments with the addition of 5,10 , and $15 \%$ jabuticaba peel flour (JPF) (Table 1). All ingredients were weighed using an analytical balance (Bel) and placed in an automatic mixing bowl (Britânia, multipane model, Brazil). For dough manufacture, the dry ingredients were mixed, followed by the wet ingredients. The manufacturing steps were mixing the ingredients, kneading, resting, $2^{\text {nd }}$ kneading, final fermentation, and cooking, according to the manufacturer's instructions of the equipment. After baking, pan bread was removed from the forms and cooled to room temperature, manually sliced (25 $\mathrm{mm}$ thickness), vacuum packed in high-density polyethylene bags, and stored at $-18^{\circ} \mathrm{C}$ until use.
Physicochemical characterization of bread and jabuticaba peel flour

The $\mathrm{pH}$ was determined using a digital potentiometer (PHS-38W). Water activity (aw) was measured in the Aqualab 4TE apparatus. Color measurements were performed in a Minolta colorimeter, CR-200 b, for luminosity (L), red (a+), green (a-), yellow (b+), blue (b-) and Chroma (C). The moisture content was determined by oven drying at $105{ }^{\circ} \mathrm{C} \pm 2{ }^{\circ} \mathrm{C}$. The nitrogen content was determined by the Kjeldahl method according to the methodology 991.20 (AOAC, 2005) and the ash content by the incineration in a muffle at $550{ }^{\circ} \mathrm{C}$. Crude fiber was determined using the methodology 920.86 (AOAC, 2005). Lipids were determined by the BLIGH \& DYER method (1959). Carbohydrates were calculated by difference.

Obtaining extract for determination of phenolic compounds and antioxidant activity of jabuticaba peel flour and bread

The extracts for analysis of total phenolics and antioxidant activity were obtained as proposed by MOORE et al. (2006) and described by LI et al. (2015), with modifications. In centrifuge tubes, about $2 \mathrm{~g}$ sample was mixed with $16 \mathrm{~mL}$ methanol acidified with $1 \% \mathrm{HCl}$. The tubes were then transferred to a water bath, protected from light and subjected to stirring $(100 \mathrm{rpm})$ for $3 \mathrm{~h}$ at $25{ }^{\circ} \mathrm{C}$. The methanolic extracts were centrifuged at $6000 \mathrm{rpm}(4350 \mathrm{x} \mathrm{g})$ for 15 min at $4{ }^{\circ} \mathrm{C}$. Supernatants were collected in amber vials and kept under refrigeration $\left(4^{\circ} \mathrm{C}\right)$.

\section{Quantification of phenolic compounds}

The content of total phenolic compounds was determined by the Folin-Ciocalteau spectrophotometric method, described by SINGLETON \& ROSSI (1965) with modifications. First, an analytical curve with different dilutions was performed using a gallic acid stock solution (200 $\mathrm{mg} \mathrm{L}^{-1}$ ), with concentrations ranging from $0 \mathrm{mg} \mathrm{L}^{-1}$ to $150 \mathrm{mg} \mathrm{L}^{-1}$. Then, $0.6 \mathrm{~mL}$ dilution of gallic acid solution $\left(\mathrm{mg} \mathrm{L}^{-1}\right)$ and $3.0 \mathrm{~mL}$ Folin-Ciocalteu reagent in water $(1: 10 \mathrm{v} / \mathrm{v})$ were transferred to test tubes, and homogenized in a tube shaker. After 3 min stirring, $2.4 \mathrm{~mL}$ saturated $\mathrm{Na}_{2} \mathrm{CO}_{3}(7.5 \% \mathrm{w} / \mathrm{v})$ was added. The tubes were allowed to stand in the dark for $1 \mathrm{~h}$, and the absorbance was read in a spectrophotometer at $760 \mathrm{~nm}$. Using the extract, one aliquot of $0.6 \mathrm{~mL}$ was transferred to test tubes and $3.0 \mathrm{~mL}$ of FolinCiocalteu reagent diluted in water $(1: 10 \mathrm{v} / \mathrm{v})$. Tubes were homogenized in a tube shaker and after $3 \mathrm{~min}$ of stirring, $2.4 \mathrm{~mL}$ saturated $\mathrm{Na}_{2} \mathrm{CO}_{3}(7.5 \% \mathrm{w} / \mathrm{v})$ 
Table 1 - Whole-grain pan bread formulations made with the addition of jabuticaba peel flour (JPF).

\begin{tabular}{|c|c|c|c|c|}
\hline Ingredients $^{*}(\%)$ & $\mathrm{T} 0$ & $\mathrm{~T} 1$ & $\mathrm{~T} 2$ & $\mathrm{~T} 3$ \\
\hline Special wheat flour & $40 \mathrm{~g}$ & $40 \mathrm{~g}$ & $40 \mathrm{~g}$ & $40 \mathrm{~g}$ \\
\hline Whole wheat flour & $60 \mathrm{~g}$ & $60 \mathrm{~g}$ & $60 \mathrm{~g}$ & $60 \mathrm{~g}$ \\
\hline Jabuticaba peel flour & 0 & 5 & 10 & 15 \\
\hline Water & 69 & 69 & 69 & 69 \\
\hline Crystal sugar & 12 & 12 & 12 & 12 \\
\hline Vegetal fat ( $80 \%$ lipids) & 3.75 & 3.75 & 3.75 & 3.75 \\
\hline Salt & 1.8 & 1.8 & 1.8 & 1.8 \\
\hline Whole milk powder & 3.0 & 3.0 & 3.0 & 3.0 \\
\hline Instant dry biological yeast & 2 & 2 & 2 & 2 \\
\hline Enzyme alpha-amylase & 1.0 & 1.0 & 1.0 & 1.0 \\
\hline Anti-mold calcium propionate & 0.2 & 0.2 & 0.2 & 0.2 \\
\hline Vital gluten & 2 & 2 & 2 & 2 \\
\hline
\end{tabular}

*\% in relation to the total weight of flour on a wet basis $(100 \mathrm{~g})$.

$\mathrm{T} 0=$ Whole-grain pan bread without the addition of jabuticaba peel flour; $\mathrm{T} 1=$ Whole-grain pan bread with the addition of $5 \%$ jabuticaba peel flour; T2 $=$ Whole-grain pan bread with the addition of $10 \%$ jabuticaba peel flour; $\mathrm{T} 3=$ Whole-grain pan bread with the addition of $15 \%$ jabuticaba peel flour.

was added. The tubes remained in the dark for $1 \mathrm{~h}$, the absorbance was read in a spectrophotometer at $760 \mathrm{~nm}$. To prepare the blank, $0.6 \mathrm{~mL}$ of water was used having the same analytical conditions described above. Results were expressed as milligrams of gallic acid equivalent per $\mathrm{g}$ of sample (mg GAE $\left.\mathrm{g}^{-1}\right)$.

\section{Determination of antioxidant activity}

The antioxidant capacity was determined by the radical 2,2-diphenyl-1-picrylhydrazyl (DPPH) assay, according to the methodology described by BRAND-WILLIAMS et al. (1995), with modifications. To quantify the antioxidant capacity, an analytical curve made with different methanolic dilutions was prepared from a Trolox stock solution $\left(1.0 \mathrm{mmol} \mathrm{L}^{-1}\right)$, with concentrations varying between $0 \mathrm{mmol} \mathrm{L}{ }^{-1}$ and $1.0 \mathrm{mmol} \mathrm{L}^{-1}$. A solution at $0.6 \mathrm{mmol}$ $\mathrm{L}^{-1} \mathrm{DPPH}$ in methanol was prepared. In the dark environment, $0.1 \mathrm{ml}$ aliquots of the Trolox solutions were transferred to test tubes, and $2.9 \mathrm{~mL}$ DPPH in methanol was added and homogenized on a tube shaker. The tubes remained in the dark for $25 \mathrm{~min}$, and absorbance was read at $515 \mathrm{~nm}$ in a spectrophotometer calibrated with methanol.

In a dark environment, $0.1 \mathrm{~mL}$ aliquot of extract was transferred to test tubes, and $2.9 \mathrm{~mL}$ DPPH in methanol was added, homogenized, and allowed to stand for $25 \mathrm{~min}$. After this period, the absorbances of extracts were read at $515 \mathrm{~nm}$ in a spectrophotometer. To prepare the blank $0.1 \mathrm{ml}$ of methanol it was used the same procedure described above. Results were expressed as $\mu \mathrm{mol}$ of Trolox per g sample ( $\mu$ mol Trolox $\left.\mathrm{g}^{-1}\right)$.

\section{Experimental design and analysis of results}

A completely randomized design with one control and three treatments $(5,10$, and $15.0 \%$ addition of JPF) and three replicates were used. Effects of the treatments were analyzed by analysis of variance (ANOVA) and the Tukey's test at 5\% significance, using the software STATISTICA version 13.0.

\section{RESULTS AND DISCUSSION}

Physicochemical characterization of jabuticaba peel flour

The jabuticaba peel flour was characterized

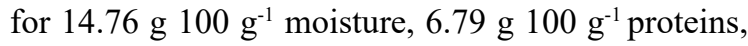

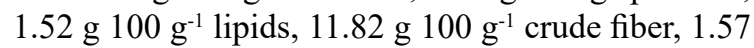

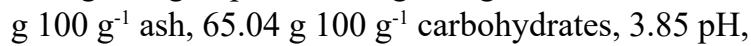
0.33 water activity (aw), $75.08 \mathrm{mg} \mathrm{GAE} \mathrm{g}^{-1}$ phenolic compounds, and $565.11 \mu \mathrm{mol}$ Trolox $\mathrm{g}^{-1}$ antioxidant activity. With respect to the color parameters, the flour exhibited $\mathrm{L}^{*}, \mathrm{a}^{*}, \mathrm{~b}^{*}$, and Chroma values of 20.77 , $13.87,4.81$, and 14.68 , respectively.

The jabuticaba peel flour (JPF) presented phenolic compounds and antioxidant activity, as well as being a source of fibers and proteins. The 
phenolic content and antioxidant activity in JPF were higher than reported by RUFINO et al. (2010) for fruit extract and LENQUISTE et al. (2015) for peel flour and lower than that reported by LEITELEGATTI et al. (2012) and LAMAS et al. (2018) for peel flour. Other extracts such as the grape peel and mulberry provided lower phenolic contents compared to our JPF (WANG et al., 2013; MEZNI et al., 2017). Probably there were phenolic losses in our JPF during the drying process in an oven with forced air circulation. Regarding colorimetry, the JPF showed a greater tendency to dark color, tending to red and yellow. The flour had average value of acid $\mathrm{pH}$ and low water activity, reaching a zone of less tendency towards enzymatic and microbiological deterioration (BONAZZI; DUMOULIN, 2011).

\section{Physicochemical characterization of pan bread}

The lowest $\mathrm{pH}$ was reported for $\mathrm{T} 3$, with no significant difference from $\mathrm{T} 2$, which did not differ from $\mathrm{T} 1$. In contrast, T0 was significantly different from all treatments, presenting a higher $\mathrm{pH}$ value $(\mathrm{P}<0.05)$ (Table 2$)$. The lower $\mathrm{pH}$ values of the formulations made with the addition of JPF may be due to the typical acidic behavior of this ingredient $(\mathrm{pH}=3.85)$.

The lowest water activity value was found in the control bread, with significant differences from the others $(\mathrm{P}<0.05)$. The JPF may have led to an increase in free water retention of pan bread, which was not observed in the control, probably because of the hydrophilic characteristics of the fibers (CHU et al., 2019).

The control bread presented a higher $\mathrm{L}^{*}$ value (46.72), differing statistically from the other treatments $(\mathrm{P}<0.05)$. Thus, the JPF favored the decrease in luminosity of the product because the JPF submit a greater tendency to dark color. Similar results were observed by BORGES et al. (2011) in bread enriched with flaxseed flour, with lower $\mathrm{L}^{*}$ values when compared to the control. The treatment T3 presented a greater red hue, with no significant differences from $\mathrm{T} 2$, which in turn did not differ from $\mathrm{T} 1$. In contrast, $\mathrm{T} 0$ differed from all other treatments $(\mathrm{P}<0.05)$. The higher $\mathrm{a}^{*}$ values observed in JPF-based formulations were due to the addition of JPF, which presented $\mathrm{a}^{*}$ value of 13.87 . The parameter $\mathrm{a}^{*}$ is also an indicative of darkening, as the brown color resulting from the degradation of sugars or enzymatic reactions (BORGES et al., 2013). Related to the coordinate $b^{*}$ and Chroma, no significant differences were observed among the treatments.

The effect of the addition of green banana (with its peel) flour as partial substitute $(10 \%$ or $20 \%)$ of wheat flour was evaluated by GOMES et al. (2016). Breads with green banana flour had lower protein content, but higher water, ash and fiber contents than the traditional bread, like reported in our results. Pan breads made with flour of yellow passionfruit's albedo and jabuticaba peel showed lower luminosity values and higher $\mathrm{a}^{*}$ values when compared to the control as also verified in this study, but the authors observed lower $b^{*}$ values, which did not occur in the present study (CONSTANTINO \& LOPES, 2019).

The control bread treatment presented higher carbohydrate, lipids and protein contents and lower fiber, moisture and ash contents when compared to other treatments (Table 2). The increase in moisture when compared to the control may be due to differences in the water absorption during dough kneading, which is influenced by the higher fiber levels in the formulations containing JPF. The addition of JPF decreased the lipid content of pan bread because JPF has lower lipid content compared to whole wheat flour.

An increase in fiber content of more than $50 \%$ was observed in $\mathrm{T} 2$ and $\mathrm{T} 3$, due to the higher fiber content of jabuticaba peel flour when compared to whole wheat flour. ESHAK (2016) reported similar crude fiber levels in bread supplemented with banana peel $(0 \%, 5 \%$, and $15 \%)$, with values of $1.42 \%, 1.97 \%$, and $2.18 \%$, respectively. A tendency to decrease the carbohydrate content was observed with the addition of JPF in bread and can be explained by the dilution of the proportion of the components due to the increase in JPF. The JPF-based formulations exhibited higher ash levels when compared to the control bread, thus evidencing the

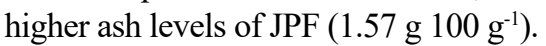

Pan breads made with flour of yellow passion fruit's albedo and jabuticaba peel showed high levels of moisture, fiber and ash, low levels carbohydrate and no differences for proteins, similar to the present study (CONSTANTINO \& LOPES, 2019). MICHELETTI et al. (2018) evaluated muffins containing different levels of jabuticaba peel flour. Higher moisture, ash and fiber levels and lower lipid and protein levels were detected in the formulation with $9 \%$ JPF, when compared to the traditional muffins. Results were similar to the present study.

\section{Phenolic compounds and antioxidant activity}

An increase $(\mathrm{P}<0.05)$ in total phenolics (Table 2) was observed with the addition of JPF to the formulations. The values reported in this study were higher than those by SECZYK et al.(2017) for wheat bread enriched with $1 \%, 2 \%, 3 \%, 4 \%$, and $5 \%$ flaxseed $\left(0.47,0.53,0.59,0.66\right.$, and $0.81 \mathrm{mg} \mathrm{GAE} \mathrm{g}^{-1}$, 
Table 2 - Proximate composition (g $100 \mathrm{~g}^{-1}$ ), phenolic compounds, antioxidant activity, physicochemical parameters, and color measurements of whole-grain pan bread made with the addition of jabuticaba peel flour.

\begin{tabular}{|c|c|c|c|c|}
\hline Parameter & T0 & $\mathrm{T} 1$ & $\mathrm{~T} 2$ & $\mathrm{~T} 3$ \\
\hline \multicolumn{5}{|c|}{ 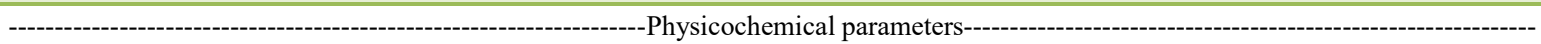 } \\
\hline $\mathrm{pH}$ & $6.25^{\mathrm{a}} \pm 0.08$ & $5.70^{\mathrm{b}} \pm 0.09$ & $5.68^{\mathrm{b}, \mathrm{c}} \pm 0.02$ & $5.36^{\mathrm{c}} \pm 0.03$ \\
\hline Aw & $0.89^{\mathrm{c}} \pm 0.01$ & $0.92^{\mathrm{b}} \pm 0.01$ & $0.93^{\mathrm{a}} \pm 0.00$ & $0.92^{\mathrm{b}} \pm 0.00$ \\
\hline \multicolumn{5}{|c|}{ 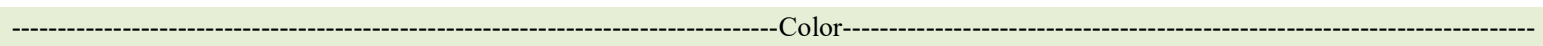 } \\
\hline $\mathrm{L}^{*}$ & $46.72^{\mathrm{a}} \pm 2.11$ & $38.97^{\mathrm{b}} \pm 2.44$ & $37.03^{\mathrm{b}} \pm 2.07$ & $36.07^{\mathrm{b}} \pm 0.85$ \\
\hline $\mathrm{a}^{*}$ & $3.10^{\mathrm{c}} \pm 0.32$ & $7.60^{\mathrm{b}} \pm 0.69$ & $8.63^{\mathrm{a}, \mathrm{b}} \pm 0.66$ & $9.07^{\mathrm{a}} \pm 0.28$ \\
\hline $\mathrm{b}^{*}$ & $13.80^{\mathrm{a}} \pm 0.76$ & $11.90^{\mathrm{a}} \pm 3.10$ & $12.75^{\mathrm{a}} \pm 0.96$ & $9.68^{\mathrm{a}} \pm 4.85$ \\
\hline Chroma & $14.19^{\mathrm{a}} \pm 0.81$ & $14.20^{\mathrm{a}} \pm 2.87$ & $15.42^{\mathrm{a}} \pm 1.13$ & $13.27^{\mathrm{a}} \pm 6.64$ \\
\hline \multicolumn{5}{|c|}{ 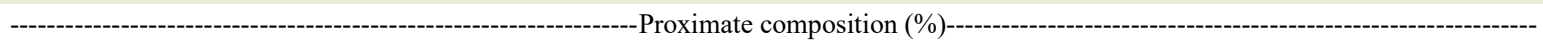 } \\
\hline Moisture & $31.06^{\mathrm{c}} \pm 11.72$ & $34.74^{\mathrm{b}} \pm 1.53$ & $37.31^{\mathrm{a}} \pm 1.61$ & $35.59^{\mathrm{a}, \mathrm{b}} \pm 1.32$ \\
\hline Protein & $10.32^{\mathrm{a}} \pm 0.50$ & $9.39^{\mathrm{b}} \pm 0.56$ & $9.37^{b} \pm 0.86$ & $9.77^{\mathrm{a}, \mathrm{b}} \pm 0.69$ \\
\hline Lipids & $4.79^{\mathrm{a}} \pm 0.36$ & $3.35^{\mathrm{c}} \pm 0.11$ & $3.73^{\mathrm{b}} \pm 0.15$ & $3.61^{b, c} \pm 0.09$ \\
\hline Crude fiber & $1.93^{\mathrm{c}} \pm 0.32$ & $2.31^{\mathrm{b}} \pm 0.18$ & $2.70^{\mathrm{a}} \pm 0.27$ & $2.91^{\mathrm{a}} \pm 0.12$ \\
\hline Carbohydrate & $51.14^{\mathrm{a}} \pm 1.70$ & $49.86^{\mathrm{a}, \mathrm{b}} \pm 2.10$ & $46.55^{\mathrm{c}} \pm 1.84$ & $47.82^{\mathrm{b}, \mathrm{c}} \pm 1.29$ \\
\hline Ash & $0.22^{\mathrm{c}} \pm 0.04$ & $0.35^{\mathrm{a}} \pm 0.08$ & $0.33^{\mathrm{a}, \mathrm{b}} \pm 0.02$ & $0.30^{b} \pm 0.53$ \\
\hline \multicolumn{5}{|c|}{----------------------------Phenolic compounds $\left(\mathrm{mg} \mathrm{GAE} \mathrm{g}^{-1}\right)$ and antioxidant activity $\left(\mu \mathrm{mol}\right.$ Trolox g $\left.\mathrm{g}^{-1}\right)$--------- } \\
\hline Phenolic compounds & $0.63^{\mathrm{c}} \pm 0.06$ & $3.03^{\mathrm{b}} \pm 0.96$ & $4.06^{\mathrm{a}} \pm 0.99$ & $4.54^{\mathrm{a}} \pm 0.23$ \\
\hline Antioxidant activity & $9.35^{\mathrm{c}} \pm 0.64$ & $23.58^{\mathrm{b}} \pm 6.44$ & $31.02^{\mathrm{a}} \pm 7.00$ & $29.94^{\mathrm{a}, \mathrm{b}} \pm 1.28$ \\
\hline
\end{tabular}

*Means followed by the same letter on the same line do not differ by Tukey's test $\mathrm{p}<0.05$. GAE $=$ Gallic acid equivalent. T0= Wholegrain pan bread without the addition of jabuticaba peel flour; $\mathrm{T} 1=$ Whole-grain pan bread with the addition of $5 \%$ jabuticaba peel flour; $\mathrm{T} 2=$ Whole-grain pan bread with the addition of $10 \%$ jabuticaba peel flour; $\mathrm{T} 3=$ Whole-grain pan bread with the addition of $15 \%$ jabuticaba peel flour.

respectively). Phenolic compounds are unstable and can easily undergo degradation, either by specific plant enzymes or the influence of metals, light, heat, or alkaline media (QUIDEAU et al., 2011). However, the phenolic compounds found in T3 were 7.00-fold higher when compared to the control sample.

With regard to the antioxidant capacity, significant differences were observed among the treatments $\mathrm{T} 0, \mathrm{~T} 1$, and $\mathrm{T} 2$, while the treatment $\mathrm{T} 3$ did not differ from $\mathrm{T} 2$ and $\mathrm{T} 1(\mathrm{P}<0.05)$. It was observed that the antioxidant activity was increased by 3.31 and 3.20 fold, respectively, in T2 and T3 when compared to the control sample. This increase is due to the concentration of phenolic compounds from JPF. Results of the antioxidant capacity reported in this study corroborate with the findings of CHLOPICKA et al. (2012). Those authors studied the effect of the addition of cereals (buckwheat, amaranth, and quinoa at $15 \%$ and $30 \%$ ) on the antioxidant properties of bread. The addition of buckwheat flour to bread, particularly at higher levels, was more effective in increasing the antioxidant activity which increased by 2.36 and 3.64 fold; respectively, when compared to amaranth and quinoa at the higher concentrations, with an increase of 1.20-1.79 and 0.60-1.71 fold, respectively, due to the higher content of phenolic compounds presented in comparison with the other cereals.

Substitution of wheat flour with $2.5 \%$, $5 \%$ and $7.5 \%$ of pomegranate peel powder for making pan breads resulted in significant increases in total phenolics and antioxidant activity as in our study (SAYED-AHMED, 2014). Other study that investigated watermelon rind powder into the formula of pan bread also observed that antioxidant potential and phenolic compounds increased in pan bread (BADR, 2015).

\section{CONCLUSION}

The addition of jabuticaba peel flour reduced the total carbohydrates, lipids and proteins of pan bread, and increased moisture, crude fiber, ash, phenolic compounds and antioxidant activity when compared to the control. Thus, the JPF has proven to be an effective ingredient to enrich food, allowing a classification as a potentially functional product. 


\section{ACKNOWLEDGEMENTS}

The authors are grateful to Fundação de Amparo à Pesquisa do Estado de Minas Gerais - FAPEMIG (Contract No. CAG - MPR-00136-16) for the financial support. This paper was carried out with the financial support of the Coordenação de Aperfeiçoamento de Pessoal de Nível Superior - Brazil (CAPES) - Financing Code 001.

\section{DECLARATION OF CONFLICT OF INTERESTS}

The authors declare no conflict of interest. The founding sponsors had no role in the design of the study; in the collection, analyses, or interpretation of data; in the writing of the manuscript, and in the decision to publish the results.

\section{AUTHORS' CONTRIBUTIONS}

All authors contributed equally for the conception and writing of the manuscript. All authors critically revised the manuscript and approved of the final version.

\section{REFERENCES}

ALEZANDRO, M. R. et al. Comparative study of chemical and phenolic compositions of two species of jabuticaba: Myrciaria jabuticaba (Vell.) Berg and Myrciaria cauliflora (Mart.) O. Berg. Food Research International, v.54, n.1, p.468-477, 2013. Available from: <https:/www.sciencedirect.com/science/ article/pii/S0963996913003840 >.Accessed: Dec. 20, 2018. doi: 10.1016/j.foodres.2013.07.018.

ASSOCIATION OF OFFICIAL ANALYTICAL CHEMISTS (AOAC). Official methods of analysis. 18nd ed. Washington: Association of Official Analytical Chemists, 2005.

BLIGH, E. G.; DYER, W. J. A rapid method of total lipid extraction and purification. Canadian Journal of Biochemistry and Physiology, v.37, n.8, p.911-917, 1959.

BADR, S. A. Quality and antioxidant properties of pan bread enriched with watermelon rind powder. Current Science International, v.4, n.1, p.117-126, 2015. Available from: $<$ https://revistas.ufpr.br/alimentos/article/view/22758>. Accessed: Mar. 02, 2020.

BONAZZI, C; DUMOULIN, E. Quality changes in food materials as influenced by drying processes. In: TSOTSAS, E.; MUJUMDAR, A. S. Modern drying technology, vol 3: Product quality and formulation. Nova Jersey: John Wiley \& Sons, 2011. cap.1, p.1-20.

BORGES, J. T. S. et al. Physico-chemical and sensory characterization of salt bread enriched with whole flaxseed flour. Boletim do Centro de Pesquisa de Processamento de Alimentos, v.29, n.1, p.83-96, 2011. Available from: <https://revistas.ufpr. br/alimentos/article/view/22758>. Accessed: Dec. 20, 2018. doi: 10.5380/cep.v29i1.22758.

BORGES, J. T. S. et al. Use of wheat and quinoa composite flour in cake making. Revista Brasileira de Tecnologia Agroindustrial, v.7 n.2, p.1034-1048, 2013. Available from: <https://revistas.utfpr. edu.br/rbta/article/view/1312>. Accessed: Dec. 20, 2018. doi: 10.3895/S1981-36862013000200004.

BRAND-WILLIAMS, W.et al. Use of a free radical method to evaluate antioxidant activity. Lebensmittel Wissenschaft and Technologie, v.28, p.25-30, 1995.

CHANG, S. K. et al. Superfruits: Phytochemicals, antioxidant efficacies, and health effects-A comprehensive review. Critical Reviews in Food Science and Nutrition, v.59, n.10, p.1580-1604, 2019. Available from: <https://doi.org/10.108 0/10408398.2017.1422111>. Accessed: Feb. 15, 2020. doi: 10.1080/10408398.2017.1422111.

CHLOPICKA, J. et al. Total phenolic and total flavonoid content, antioxidant activity and sensory evaluation of pseudocereal breads. Food Science and Technology, v.46, n.2, p.548-555, 2012. Available from: $<$ https://www.sciencedirect.com/science/ article/pii/S0023643811003641>. Accessed: Dec. 20, 2018. doi: 10.1016/j.lwt.2011.11.009

$\mathrm{CHU}$, J. et al. Improved physicochemical and functional properties of dietary fiber from millet bran fermented by Bacillus natto. Food Chemistry. v.294, p.79-86, 2019. Available from: <https://www. sciencedirect.com/science/article/pii/S0308814619308313\#b0040>. Accessed: Jul. 04, 2019. doi: 10.1016/j.foodchem.2019.05.035.

CONSTANTINO, J. S. F., LOPES, D. L. Desenvolvimento de pão de forma contendo farinha mista de maracujá e jabuticaba. In: CARDOSO, N.A. et al. As ciências biológicas e da saúde na contemporaneidade 2. Ponta Grossa: Atena Editora, 2019. p.127-142.

ESHAK, N. S. Sensory evaluation and nutritional value of balady flat bread supplemented with banana peels as a natural source of dietary fiber. Annals of Agricultural Sciences, v.61, n.2 p.229235, 2016. Available from: <https://www.sciencedirect.com/ science/article/pii/S0570178316300227>. Accessed: Dec. 20, 2018. doi: 10.1016/j.aoas.2016.07.002.

FERREIRA, A. E. et al. Production, characterization and use of jaboticaba flour in cookie type cookies. Brazilian Journal of Food and Nutrition, v.23, n.4, p.603-607, 2012. Available from: $<$ https://doaj.org/article/f702625412af418e813679d08eff2c88>. Accessed: Dec. 20, 2018.

FREITAS-SÁ, D. G. C. et al. Effect of jabuticaba (Myrciaria jaboticaba (Vell) O. Berg) and jamelão (Syzygium cumini (L.) Skeels) peel powders as colorants on color-flavor congruence and acceptability of yogurts. Food Science and Technology, v.96, p.215-221, 2018. Available from: <https://www.sciencedirect. com/science/article/pii/S0023643818304389>. Accessed: Jan. 30, 2020. doi: 10.1016/j.lwt.2018.05.024.

GOMES, A. A. B. et al. Bread with flour obtained from green banana with its peel as partial substitute for wheat flour: Physical, chemical and microbiological characteristics and acceptance. International Food Research Journal, v.23, n.5, p.2214-2222, 2016. Available from: $<$ https://www.researchgate.net/publication/309578141>. Accessed: Feb. 15, 2020 .

GURAK, P. D. et al. Jaboticaba pomace powder obtained as a coproduct of juice extraction: A comparative study of powder obtained from peel and whole fruit. Food Research International, v.62, p.786-792, 2014. Available from: <https://www.sciencedirect. com/science/article/pii/S0963996914002919>. Accessed: Feb. 20, 2020. doi: 10.1016/j.foodres.2014.04.042. 
LAMAS, C. A. et al. Jaboticaba extract prevents prediabetes and liver steatosis in high-fat-fed aging mice. Journal of Functional Foods, v.47, 2017, p.434-446, 2018. Available from: <https:// www.sciencedirect.com/science/article/pii/S1756464618303013>. Accessed: Jan. 30, 2020. doi: 10.1016/j.jff.2018.06.005.

LEITE-LEGATTI, A.V. et al. Jabuticaba peel: antioxidant compounds, antiproliferative and antimutagenic activities. Food Research International, v.49, n.1, p.596-503, 2012. Available from: <https://www.sciencedirect.com/science/article/ pii/S0963996912002888>. Accessed: Dec. 20, 2018. doi: 10.1016/j. foodres.2012.07.044.

LENQUISTE, S. A. et al. Jaboticaba peel and jaboticaba peel aqueous extract shows in vitro and in vivo antioxidant properties in obesity model. Food Research International, v.77, p.162170, 2015. Available from: <http://dx.doi.org/10.1016/j. foodres.2015.07.023>. Accessed: Mar. 02, 2020. doi: 10.1016/j. foodres.2015.07.023.

LI, Y. et al. Total phenolic, flavonoid content, and antioxidant activity of flour, noodles, and steamed bread made from different colored wheat grains by three milling methods. The Crop Journal, v.3, n.4, p.323-334, 2015. Available from: <https:// www.sciencedirect.com/science/article/pii/S2214514115000471>. Accessed: Dec. 20, 2018. doi: 10.1016/j.cj.2015.04.004.

LIMA, A.J.B. et al. Chemical characterization of the jabuticaba fruits (Myrciaria cauliflora Berg) and their fractions. Archivos Latinoamericanos de Nutrición, v.58 n.4, p.416421, 2008. Available from: <http://ve.scielo.org/scielo. php?script $=$ sci_arttext\&pid $=$ S0004-06222008000400015>. Accessed: Dec. 20, 2018.

MEZNI, A. et al. Lithium induced oxidative damage and inflammation in the rat's heart: Protective effect of grape seed and skin extract. Biomedicine \& Pharmacotherapy, v.95, 2017. Available from: <http://dx.doi.org/10.1016/j.biopha.2017.09.027> Accessed: Mar. 16, 2020. doi: 10.1016/j.biopha.2017.09.027.

MICHELETTI, J. et al. The addition of jaboticaba skin flour to muffins alters the physicochemical composition and their sensory acceptability by children. Brazilian Journal of Food Technology, v.21, e2017089, 2018. Available from: <http:// www.scielo.br/scielo.php? script $=$ sci_arttext\&pid $=\mathrm{S} 1981$ 67232018000100439\&lng=en\&nrm=iso $>$. Accessed: Dec. 16, 2019. doi: 10.1590/1981-6723.08917.

MOORE, J. et al. Effects of genotype and environment on the Antioxidant Properties of Hard Winter Wheat Bran. Journal of Agricultural and Food Chemistry, v.54 n.15 p.5313-5322, 2006. Available from: $<$ https://pubs.acs.org/doi/abs/10.1021/jf0603811 > Accessed: Dec. 20, 2018. doi: 10.1021/jf0603811.

OLIVEIRA, C. D. et al. Physical-chemical characterization of yogurt type sundae jabuticaba flavor. Brazilian Journal of Development, n.6, p.5091-5097, 2019. Available from: <http:// www.brazilianjournals.com/index.php/BRJD/article/view/1700>. Accessed: Jan. 30, 2020

PLAZA, M. et al. Characterization of antioxidant polyphenols from Myrciaria jaboticaba peel and their effects on glucose metabolism and antioxidant status: A pilot clinical study. Food Chemistry, v.211, p.185-197, 2016. Available from: <https://
www.sciencedirect.com/science/article/pii/S0308814616307063>. Accessed: Feb. 06, 2020. doi: 10.1016/j.foodchem.2016.04.142.

QUATRIN, A. et al. Characterization and quantification of tannins, flavonols, anthocyanins and matrix-bound polyphenols from jaboticaba fruit peel: A comparison between Myrciaria trunciflora and M. jaboticaba. Journal of Food Composition and Analysis, v.78, p.59-74, 2019. Available from: $<$ https://www.sciencedirect.com/ science/article/ pii/S0889157518304022>. Accessed: Feb. 15, 2020. doi: 10.1016/j.jfca.2019.01.018.

QUIDEAU, S. et al. Plant polyphenols: chemical properties, biological activities, and synthesis. Angewandte Chemie International Edition, v.50, n.3, p.586-621, 2011. Available from: $<$ https://onlinelibrary.wiley.com/doi/full/10.1002/anie.201000044>. Accessed: Dec. 20, 2018. doi: 10.1002/anie.201000044.

RUFINO, M. S. M. et al. Bioactive compounds and antioxidant capacities of 18 non-traditional tropical fruits from Brazil. Food Chemistry, v.121, n.4, p.996-1002, 2010. Available from: $<$ https:// doi.org/10.1016/j.foodchem.2010.01.037>. Accessed: Dec. 20, 2018. doi: 10.1016/j.foodchem.201001037.

SAYED-AHMED, E. F. Evaluation of pomegranate peel fortified pan bread on body weight loss. International Journal of Nutrition and Food Sciences, v.3, n.5, p.411-420, 2014. Available from: $<$ https://www.researchgate.net/publication/287139686_Evaluation of Pomegranate Peel Fortified Pan Bread on Body Weight Loss $>$. Accessed: Mar. 01, 2020. doi: 10.11648/j.ijnfs.20140305.18.

SECZYK, Ł. et al. Antioxidant, nutritional and functional characteristics of wheat bread enriched with ground flaxseed hulls. Food Chemistry, v.214, p.32-38, 2017. Available from: <https:// www.sciencedirect.com/science/article/pii/S0308814616310901>. Accessed: Dec. 20, 2018. doi: 10.1016/j.foodchem.2016.07.068.

SINGLETON, V. L.; ROSSI, J. A. Colorimetry of Total Phenolics with Phosphomolybdic Phosphotungstic Acid Reagents. American Journal of Enology and Viticulture, v.16, p.144-158, 1965.

STORCK, C. R. et al. Leaves, stalk, pell and seeds of vegetables: Nutritional composition, utilization and sensory analysis in food preparations. Ciência Rural, v.43, n.3, p.537-543, 2013. Available from: $<$ http://www.scielo.br/scielo.php?script=sci ar ttext\&pid=S0103-84782013000300027>. Accessed: Feb. 12, 2020. doi: 10.1590/S0103-84782013000300027.

WANG, Y. et al. Antidiabetic and antioxidant effects and phytochemicals of mulberry fruit (Morus alba L.) polyphenol enhanced extract. Plos One, v.8, n.7, e71144, 2013. Available from: $<$ https://www.ncbi.nlm.nih.gov/pmc/articles/PMC3728024>. Accessed: Feb. 15, 2020. doi: 10.1371/journal.pone.0071144.

WU, S. B. et al. Metabolite profiling of jaboticaba (Myrciaria cauliflora) and other dark-colored fruit juices. Journal of Agricultural and Food Chemistry, v.60, n.30, p.7513-7525, 2012. Available from: $<$ https://pubs.acs.org/doi/10.1021/jf301888y $>$. Accessed: Feb. 15, 2020. doi: $10.1021 /$ jf301888y.

WU, S. B. et al. Phytochemistry and health benefits of jabuticaba, an emerging fruit crop from Brazil. Food Research International, v.54, n.1, p.148-159, 2013. Available from: <https://www. sciencedirect.com/science/article/pii/S0963996913003487>. Accessed: Dec. 20, 2018. doi: 10.1016/j.foodres.2013.06.021. 